UDK 378.147

DOI 10.22363/2312-8631-2017-14-1-59-68

\title{
FEATURES OF FOREIGN STUDENTS PRE-UNIVERSITY MATHEMATICAL TRAINING
}

\author{
N.A. Pykhtina \\ Peoples' Friendship University of Russia \\ Miklukho-Maklaya str., 6, Moscow, Russia, 117198
}

The aim of improving the international competitiveness of the higher education Russian system at the global level by increasing the number of foreign students leads to the fact, that pre-university training is becoming essential for next years at higher educational programmes.

Pre-university mathematical training of international students contributes to the scientific style formation of speech skills, which is so useful in higher educational institute. This article highlights some of the features of foreign students pre-university mathematical training.

Design of "Mathematics" course methodical ware for preparatory departments of higher educational institutions is an important element of the educational process. Features of mathematics teaching are shown by the example of such important for foreign students pre-university mathematical training branch of mathematics like the set theory.

The article also gives consideration to such aspects of mathematics teaching for foreign students as the inclusion of text mathematical problems in the "Mathematics" course programme for helping to achieve lexical skills and abilities, as well as the organization of individual work of the students with the use of information and communication technologies.

The paper refers to the collection of exercises and tasks for the "Mathematics" course for foreign citizens studying at the preparatory departments of higher educational institutions, it additionally gives the themes of the course.

Key words: higher education, international students, preparatory departments of higher educational institutions, pre-university mathematical training, scientific style of speech, individual work, information and communications technologies

Pre-university training issues for the successful continuation at higher educational programmes in Russian are needed for mainstreaming with the aim of improving the international competitiveness of the higher education Russian system at the global level by increasing the number of foreign students.

Up to statistics from the Ministry of Education and Science of the Russian Federation in 2013-2014 academic year the number of foreign citizens studying in Russian higher education institutions amounted to 250,2 thousand people. The total number of students in this period -5647 thousand people. Thus, foreign students are $4,43 \%$ of all students of Russian universities [1].

Mostly foreigners should study in Russian at the higher educational programmes, so in the first year they become students of preparatory departments (in 2013-2014 academic year 12682 people were studing at such programmes). With the aim of successful continuation to study at higher educational programmes such departments of universities 
offer pre-university training at the Russian language and general educational subjects. These subjects correspond to the profile of chosen field of study.

At the III All-Russian Congress "School Math Education”, which took place in November 2015, in Novosibirsk, important and significant theses were put forward and mentioned in the resolution. One of them concerns expediency of mathematical courses introduction in 1-2 years students programmes at all specialties of higher education to ensure required level of mathematical training for the needs of economy, security and scientific and technical progress [2].

So, problem of foreign students mathematics teaching at the preparatory departments of Russian higher educational institutions becomes more and more actual.

First of all, we are interested in the connection between Russian language learning and mathematical training with the aim of students successful studies continuance at directions and specialties of higher education at 1-2 years.

Higher educational institutions have a special task to create mathematical competence at students who study at different directions and specialties, as mathematical phenomenon is widely used in almost all fields of science. The "Mathematics" course is prepared almost in all study groups of foreign students at the universities preparatory departments. This course should be carried as a special tool for logical connections and abstract designs building, but not as just a set of theorems, formulas and problems.

In our paper features of foreign students pre-university mathematical training will be highlighted. And we will show their importance at students individual work organization by using information and communication technologies.

The essential feature is that at the mathematical classes with foreign students not only subject specific competences are formed, but also lexical skills and abilities are developed.

The reason of that fact is that mathematics has a supranational characteristics, when the textbooks of any country in the world has a similar logic and structured order of material. So such discipline easier helps international students to form communicative competence for communication in sphere of study and science.

Thus, one of the "Mathematics" course aim for foreign students at the preparatory departments of higher educational institutions is their possession of lexical structures of the Russian language in mathematics, as well as terminology, which is necessary for successful study continuation at higher educational programmes.

We can achieve this aim with the help of repeating, in some cases of incoming applicant countries it is not repeating, but studying, materials of Russian school mathematics in Russian language. Foreign students at the preparatory departments of higher educational institutions begin "Mathematics" course studying after they have got some initial knowledge in Russian at elementary level and scientific style of speech.

Next feature is actuality of disciplines conjugation, such foreign students study at the preparatory departments of Russian higher educational institutions. In our case interconnection between Russian language learning and students mathematical training for successful studies continuance at directions and specialties of higher education at 1-2 years is very important.

The other feature of mathematics training for foreign students at the preparatory departments of higher educational institutions is the importance not only courses contents 
study, but mathematical language study to develop the ability of thinking in their native language.

In this case acquirement of "Russian mathematical language" by foreign students has the lead role in the development of teaching methods at preparatory mathematics course in Russian language in terms of pre-university foreign citizens education [3. P. 64].

Traditionally, mathematics is considered like educational area where minimum language skills are required, as it is not connected with texts writing or analysis. Mathematics is often regarded as a set of rules and some symbols manipulation that has no links with oral and written language.

The reason of that could be caused by the fact of the existence operations with numbers, symbols and equations at the elementary mathematics.

Advanced mathematics courses in higher educational institutes require understanding of the relationship between the various concepts. This situation can cause difficulties between foreign students. In mathematics courses we can distinguish two components:

- procedural (formulas, symbols and others)

- conceptual (definition of concepts, proof and conclusion of new, logical reasoning and others).

The conceptual component does help transit from elementary mathematics concepts to developing of mathematically thinking ability, as well as clarifies connection between language skills and mathematics.

But in practice it often happens that foreign students have difficulties with remembering and uses of "classic" formulation of definitions, theorems and their proof, which are common in mathematics.

Therefore, for foreign students at the preparatory departments of higher educational institutions we should use "Mathematics" stable constructions, special vocabulary (oral and written language) for specific rules and structures, as well as give several versions of formulations. Often foreign students have difficulties not only because of the problems of Russian language, but also because of the different levels of mathematics knowledge.

To compare different levels of quality international education in some foreign countries in the world International study of Trends in Mathematics and Science Study (TIMSS) takes place. It is the most representative studies of school education, 600,000 students from 63 countries participated in 2011. The results of the 2015 year study with about 60 countries participants could be available at the end of 2016 [4].

The goal of TIMSS study is comparative assessment of school education in mathematics and science at many countries with different education systems, revealing features of educational systems that determine different levels of student achievement.

There is one more important aspect in "Mathematics" course teaching for foreign students, we should take into account investigation of materials and rules of main exams that applicants pass for admission to universities. The reason of this is that methods of evaluation and contents of test materials in any education system are one of its essential characteristics.

So different factors should be considered during "Mathematics" course teaching at preparatory departments of higher educational institutions developing:

- level of basic applicants mathematics knowledge,

- differences in demands in variety of applicants country, 
- consequent learning of Russian language in parallel with "Mathematics" course teaching,

- conjugation of all disciplines in whole students training programme at preparatory department,

- necessity to form communicative competence for communication in sphere of study and science with the help of lexical structures of the Russian language in mathematics.

The reason of that fact is that mathematics has a supranational characteristics, when the textbooks of any country in the world has a similar logic and structured order of material. So such discipline easier helps international students to form communicative competence for communication in sphere of study and science.

As we mentioned above it's worth using stable constructions and giving several versions of formulations during "Mathematics" course teaching. For instance, construction "If ..., then ...". We can use it from the first classes, when students have an introduction in mathematical terminology:

- if expression contains only multiplication and division, then do them consequently (from left to right),

- if the sum of the digits of the number can be divided by 3 , then the number itself is divisible by 3 .

Or the other example of symbol note $a A$, when we can give students several variants of its reading:

- $a$ is an element of set $A$,

- element a belongs to set $A$,

- set $A$ contains element $a$.

As we can see in these two examples the verb "to contain" is repeated, it's important to pay attention of foreign students on this observation.

To create modern studying process for foreign students at the preparatory departments of higher educational institutions mutual work of Russian language, mathematics and computer science teachers is required. Now only their joint actions can activate and raise at new level the system of students basic communicative competence formation, as well as improve their skills of scientific style of speech with the use of modern software and hardware tools and information technology.

Consequently integration between pedagogic and information technologies should be held in sphere of learning and teaching. The teacher should use modern information (digital) tools of teaching at his job.

Actual demands of students training lead to information and communications technologies using for key competence formation.

Nowadays new ways of internet-technologies using are the results of information technologies progress under world globalization. We can observe consequent and stable trend of information society building, which aims to create best conditions for maximum self-realization of each person. This is reflected with active computer and telecommunication technologies development and informational and educational environment creation.

Thus we should actively apply online resources in the sphere of education. Information technologies implementation into studying process has become more vital in teaching. Internet plays the leading role among telecommunication technologies. Teachers can vary their educational technologies with different tools of multimedia technologies. 
Materials for foreign students at the preparatory departments of higher educational institutions especially if they are in electronic format should satisfy some requirements:

- clear and plain written and adapted to the level of students' knowledge,

- logically structured,

- contain verbal examples and textual problems with different lexical content.

We will show this at the example of such important for foreign students pre-university mathematical training branch of mathematics like the set theory, because it is in almost all areas of mathematics and includes in its basis.

As we mentioned above "Scientific style of speech" course precedes "Mathematics" course. Generally at scientific style of speech classes students learn to read numbers including fractions, learn system of real numbers, arithmetical actions and their components. So "Mathematics" course should be started with fast repeating of this materials with reference of different numbers' kinds (integers, negative, fractions). And after this go to the "naive" set theory, which can be met in almost each branch of mathematics.

Set theory learning at the beginning of "Mathematics" discipline is very important for foreign students at the preparatory departments of higher educational institutions. So, we give some reasons of that fact:

At first, the set theory lies at the basis of all branches of mathematics, that is why it allows mathematical terminology and lexical structures using in further learning.

For instance, like in above example with symbol note $a \in A$, when we can give students several variants of its reading using different verbs "to be", "to belong", "to contain".

At the same way these verbs could be used with introduction of subset concept, when symbol note $B \subset A$ means:

$-B$ is an subset of set $A$,

- set $B$ belongs to set $A$,

- set $A$ contains subset $B$.

The teacher can from note $a \in A$ on the whiteboard and its three types of reading make note for $B \subset A$ just replacing the element $a$ on the subset $B$. Thereby he demonstrates to students two similar constructions.

Or the note $A=\left\{a_{1} ; a_{2} ; a_{3} ; \ldots\right\}$ means that set $A$ consists of elements $a_{1}, a_{2}, a_{3}, \ldots$

Highlighted verbs "to be", "to belong", "to contain", "to consist of" are often used in further "Mathematics" course and also in everyday life. It's worth mention examples of these verbs using for better remembering them by students (cellphone belongs to Anna, the book contains 68 pages, the textbook consists of five chapters).

Secondly, the set theory does not contain lots of formulas, equations, calculations, so it better helps to form skills and abilities in different kinds of speech activity.

As it was shown above at the examples, the teacher invents for students various semantic models during their set theory study including such substantial aspects like set operations, Euler-Venn diagrams, numerical sets. These models help foreign students better learning and confirming of mathematical terminology, as well as give opportunity to see all details of scientific language construction.

So, thirdly this part of "Mathematics" course assists foreign students to develop their skills in scientific style of speech proficiency. 
And finally, the last one, fourthly verbal examples and textual problems with different lexical content play important role in set theory learning and its demonstration.

Here are some examples of sets:

- set of students in the audience,

- set of students of the preparatory faculty,

- set of students who live in the dorm,

- set of students from Latin America,

- set of tables and chairs in the audience,

- set of audiences in the building.

Here are some examples of subsets:

- set of the textbook pages and its subset - pages that Peter read,

- set of students from Latin America and its subset - students from Mexico,

- set of university students and its subset - students from preparatory faculty,

- set of the furniture in the building and its subset - tables and chairs in the audience.

Here are some examples of set operations:

- equality of two sets: the set of students of the preparatory faculty and the set of students learning Russian language at the programmes of this faculty,

- equality or inequality of the set of students in the classroom and the set of students in the study group (usually these sets are rarely equal),

- union of the set of students involved in sports section and the set of students involved in amateur performances is the set of students who participate in extra-curricular life of the university,

- union of three sets: the set of students who know English language, the set of students who know French language and the set of students who know Spanish is the set of students who speak foreign language,

- intersection of two sets: the set of Arab students and the set of students who came from Europe is the set of Arab students from European countries,

- intersection of two sets: the set of book pages Anna read and the set of book pages Peter read, is the set of book pages that Anna and Peter read,

- difference between the set of foreign students and the set of students learning Russian language is the set of compatriots (they have foreign citizenship and speak Russian).

In given examples we use vocabulary which students already known, so they can learn new terms and lexical structures based on previously studied. Examples of such kinds strongly react to the audience and students themselves are actively involved in thinking up with their own examples.

There are a smart few typical textual problems on "Set theory" theme. Lexical content in these problems could be different depending on each type of such problem. Typically problems with lexis about university life like shown above are chosen for foreign students at the preparatory departments of higher educational institutions. But sometimes we can give students a problem with ordinary language style. In practice such problems occupy attention of foreign students and arouse interest not only in the problem's text, but in its solution searching.

Let's give an example of such problem: How many children are in family, if 7 of them like cabbage, 6 - carrots, 5 - peas, $4-$ cabbage and peas, 3 - cabbage and peas, $2-$ carrots and peas, and 1 like cabbage, peas and carrots? [5. P. 86]. 
The set-theoretic approach creates friendly environment for target Russian mathematical language studies and promotes scientific style of speech skills development. Main means for set-theoretic concepts formation by foreign students and abilities to use them are verbal examples and textual problems with specially selected different lexical content that leads to students' vocabulary actuation.

The system of education in Russia has been changing and in the other countries either. Paradigm of education is changing too. So we have another teacher's role in studying process, now he should manage knowledge weeding out all unnecessary and unreliable materials. Such modern trends touch on the system of foreign students pre-university training.

Organization of student's individual work has been affected by these changes. Teenagers just out of school have lots of problems with adaptation to university life; they don't know how to learn by themselves, they need a high level of self-organization and motivation. At the preparatory departments of higher educational institutions there is also comprehensive adaptation for foreign students.

Active implementation of distant learning technology for students pre-university training can lead to the situation when being a university student he would be unable to study in another environment, because he doesn't possess immunity to stressful situations, adaptation to training system, climate, etc. The development of information technology is an obvious prospect, which requires, however, a reasonable combination with traditional teaching methods.

Considering the importance of student's individual work organization, teachers develop special syllabuses. Nowadays self-study with electronic learning resources use became more valued. A teacher should create intellectual skills in students with applying complex of study guide, textbooks and learning resources through tasks at individual work.

Every year at the faculty of the Russian language and general educational disciplines of the Peoples' Friendship University of Russia lots of course books and study materials are prepared. Recently at the Department of Mathematics and Computer Science the collection of exercises and tasks for the "Mathematics" course for individual work of students of medical and biological areas of training the faculty of Russian language and general educational disciplines has been prepared.

This collection involves different textual mathematical problems that contribute to subject specific competences formation, as well as lexical skills and abilities achievement. Exercises and problems are divided by themes:

1. Natural numbers (includes exercises and problems)

2. Whole numbers. Arithmetic operations and their order (includes exercises and problems)

3. Congruence of numbers. Divisibility property (includes exercises and problems)

4. Divisibility rules. Lowest common multiple, greatest common divisor (includes exercises and problems)

5. Degree. The formulas of abridged multiplication (includes exercises and problems)

6. Fraction (includes exercises and problems)

7. Decimal fraction (includes exercises and problems)

8. Numerical sets. Number scale (includes exercises and problems)

9. Numerical intervals. Modulus (includes exercises and problems)

10. Ratios. Proportions. Percentages (includes exercises and problems) 
11. Arithmetic square root. Arithmetic root of degree $n$ (includes exercises and problems)

12. Rectangular coordinate system. Quadratic polynomial factorization (includes exercises)

13. Quadratic equations, rational equations. Inequalities (includes exercises and problems)

14. Function. Function properties (includes exercises and problems)

15. Quadratic function (includes exercises and problems)

16. nth root. Degree with rational exponent (includes exercises)

17. Power function (includes exercises)

18. Exponential function. Exponential equations (includes exercises)

19. Logarithm function. Logarithm equations (includes exercises)

20. Trigonometric functions (includes exercises)

In this way, at the preparatory departments of higher educational institutions it's very important to create basis of subject specific competences formation, but also lexical progress especially for scientific style of speech abilities. All these facts require special professional competences and guidance papers developing by teachers. To do this, a teacher is obliged to know the basics of pedagogical design and to improve his information culture.

\section{LITERATURE}

[1] Экспорт российских образовательных услуг: Статистический сборник. Выпуск 5 / Министерство образования и науки Российской Федерации. М.: Социоцентр, 2015. 416 с.

[2] Резолюция III Всероссийского съезда «Школьное математическое образование» (г. Новосибирск, 17-18 ноября 2015 г.). URL: http://rusacademedu.ru/wp-content/uploads/2015/10/ rezoljucija-iii-vserossijskogo-sezda-shkolnoe-matematicheskoe-obrazovanie.pdf

[3] Кузнецова T.И. Оптимизация преподавания математики на подготовительных факультетах для иностранных граждан вузов России // Образовательные технологии. 2013. № 2. С. $64-$ 75.

[4] Международное исследование по оценке качества математического и естественнонаучного образования. URL: http://www.centeroko.ru/timss15/timss15.htm

[5] Спивак A.B. Тысяча и одна задача по математике: Кн. для учащихся 5-7 кл. М.: Просвещение, 2002. 2007 с.

(C) Pykhtina N.A., 2017

\section{Article history:}

Received: 3 October 2016

Accepted: 14 November 2016

For citation:

Pykhtina N.A. Features of foreign students pre-university mathematical training // RUDN Journal of Informatization Education. 2017. 14 (1). 59-68.

\section{Bio Note:}

Pykhtina Natalya Aleksandrovna, candidate of pedagogical sciences, senior teacher of department of mathematics and informatics of the Russian Peoples' Friendship University.

Contact information: e-mail: n.vostrikova@mail.ru. 


\title{
ОСОБЕННОСТИ ПРЕДВУЗОВСКОЙ МАТЕМАТИЧЕСКОЙ ПОДГОТОВКИ ИНОСТРАННЫХ СТУДЕНТОВ
}

\author{
Н.А. Пыхтина \\ Российский университет дружбы народов \\ ул. Миклухо-Маклая, 6, Москва, Россия, 127521
}

Стремление повысить международную конкурентоспособность российской системы высшего образования на глобальном уровне за счет увеличения числа иностранных студентов приводит к необходимости актуализации проблем предвузовской подготовки для успешного продолжения обучения по образовательным программам высшего образования на русском языке.

Предвузовская математическая подготовка иностранных студентов формирует предметные компетенции, а также навыки владения научным стилем речи, такие необходимые в учебнонаучной среде вуза. В данной статье выделены некоторые особенности предвузовской математической подготовки иностранных студентов.

Важным элементом организации учебного процесса является разработка методического обеспечения курса «Математика» для подготовительного отделения вуза. На примере такого важного раздела курса «Математика» на этапе предвузовской математической подготовки иностранных граждан, как теория множеств показаны особенности преподавания математики.

Также уделено внимание таким аспектам преподавания математики иностранным студентам, как включение текстовых математических задач в программу курса «Математика» для развития лексических навыков и умений, а также организации самостоятельной работы студентов с использованием информационно-коммуникационных технологий.

В статье говорится о сборнике упражнений и задач для курса «Математика» для иностранных граждан, обучающихся на подготовительных отделениях образовательных организаций высшего образования, приводятся темы курса.

Ключевые слова: высшее образование, иностранные студенты, подготовительное отделение вуза, предвузовская математическая подготовка, научный стиль речи, самостоятельная работа, информационно-коммуникационные технологии

\section{REFERENCES}

[1] Jeksport rossijskih obrazovatel'nyh uslug: Statisticheskij sbornik [Export of Russian educational services: Statistical compilation]. Vypusk 5 / Ministerstvo obrazovanija i nauki Rossijskoj Federacii [Issue 5 / Ministry of Education and Science of the Russian Federation]. M.: Sociocentr, 2015. $416 \mathrm{p}$.

[2] Rezolyutsiya III Vserossijskogo s"ezda «Shkol'noe matematicheskoe obrazovanie» (g. Novosibirsk, 17-18 noyabrya 2015 g.) [Resolution III All-Russian Congress "School Math Education", Novosibirsk, 17-18 November 2015]. URL: http://rusacademedu.ru/wp-content/uploads/2015/10/ rezoljucija-iii-vserossijskogo-sezda-shkolnoe-matematicheskoe-obrazovanie.pdf

[3] Kuznetsova T.I. Optimizatsiya prepodavaniya matematiki na podgotovitel'nykh fakul'tetakh dlya inostrannykh grazhdan vuzov Rossii [Optimization of mathematics teaching at the preparatory departments for foreign students in Russian universities] // Obrazovatel'nye tekhnologii [Educational technologies]. 2013. No. 2. Pp. 64-75.

[4] Mezhdunarodnoe issledovanie po otsenke kachestva matematicheskogo i estestvennonauchnogo obrazovaniya [An international study about quality of mathematics and science education assessment]. URL: http://www.centeroko.ru/timss15/timss15.htm

[5] Spivak A.V. Tysyacha i odna zadacha po matematike: Kn. dlya uchashhikhsya 5-7kl. [One Thousand and one problem in mathematics: Bk. for pupils of 5-7 forms]. M.: Prosveshhenie, 2002. 2007 p. 


\section{История статьи:}

Дата поступления в редакцию: 3 октября 2016

Дата принятия к печати: 14 ноября 2016

\section{Для цитирования:}

Пыхтина Н.А. Особенности предвузовской математической подготовки иностранных студентов // Вестник Российского университета дружбы народов. Серия «Информатизация образования». 2017. Т. 14. № 1. С. 59-68.

\section{Сведения об авторе:}

Пыхтина Наталья Александровна, кандидат педагогических наук, старший преподаватель кафедры математики и информатики Российского университета дружбы народов.

Контактная информация: e-mail: n.vostrikova@mail.ru. 